\title{
Cytopathological Changes Induced by Yellow Vein Mosaic Virus in Mid-Vein of Infected Okra Plant
}

\author{
V.K. Markam ${ }^{1}$, A.K. Singh ${ }^{1}$, Narayan Lal $^{2}$ and Shailendra Kumar ${ }^{3}$ \\ ${ }^{1}$ Department of Plant Pathology, IGKV, Raipur, CG, India \\ ${ }^{2}$ Department of Horticulture, ${ }^{3}$ Department of Entomology, JNKVV, Jabalpur, MP, India \\ *Corresponding author
}

\section{A B S T R A C T}

\section{Keywords \\ Cytopathological, \\ Azure stain A, \\ Veins, \\ Nucleoprotein. \\ Article Info \\ Accepted: \\ 29 May 2017 \\ Available Online: \\ 10 June 2017}

In the present cytopathological study, phloem cells of diseased mid-vein retained the Azure A stain indicating the presence of foreign deoxy-ribo-nucleoprotein in comparison to healthy one. Inclusion bodies were found associated with the nucleus of diseased mid-vein phloem cells. Azure A stain imparts red magenta color to the inclusions rich in ribo-nucleoprotein and blue to blue violet color to inclusion rich in deoxy-ribo-nucleoprotein. At higher magnification, inclusion bodies with the diseased mid-vein phloem cells were clearly visible associated with the nucleus in comparison to healthy mid-vein phloem cells of okra plants.

\section{Introduction}

Okra (Abelmoschus esculentus (L.) Moench), belonging to the Malvaceae family, was believed to be originated in tropical Africa (Akanbi et al., 2010). It is an important vegetable crop in the tropical and subtropical region of the world (Kumar et al., 2010). Stem of okra is used for paper making in paper mills. Okra is a good source of vitamin A, B, C and protein, carbohydrates, fats, minerals, iron and iodine (Baloch et al., 1990). Consumption of $100 \mathrm{~g}$ of fresh okra fruit provides 20,15 and $50 \%$ of the daily requirement of calcium, iron and ascorbic acid, respectively. This vegetable is attacked by a number of fungi, bacteria, viruses, phytoplsma, nematodes and insects. The total loss, on this vegetable, has been estimated upto $20-30 \%$ but if pathogens attack in early age of plant, this loss may increase up to 8090\% (Hamer and Thompson, 1957). Deshmukh et al., (2011) reported that okra production got major setback due to the severe incidence of yellow vein mosaic virus (YVMV), a gemini virus, in India. The existing commercial varieties/ hybrids are vulnerable to YVMV. It has been observed that degree of resistance varies from locality to locality and season to season. The different virus and vector strains play an important role in expression of disease. Available commercial varieties/hybrids are highly susceptible to the YVMV. The infected plants bear whitish yellow fruits, which are not fit for marketing and therefore, farmers suffer from economic losses. Plants infected at 50 and 65 days, after germination, suffer a loss 
of 84 and 94\%, respectively (Sastry and Singh, 1974).

Viruses pose serious constraints to okra production. These viruses severely affect okra production in terms of yield and fruit quality. Among these viruses, yellow vein mosaic virus (YVMV) causes significant loss in the okra production. YVMV was first reported in 1924, (Kulkarni, 1924) at Bombay Presidency in India. This virus is a member species of genus Begomovirus in family Geminiviridae (Fauquet and Stanley, 2005). YVMV is believed to be originated from India (Usha, 2008). YVMV, transmitted by white fly (Bemisiatabaci Gen.), is the most serious disease of okra. Infection of $100 \%$ plants in the field is very usual and yield losses range from $50 \%$ to $94 \%$ depending on the stage of crop growth at which infection occurs (Sastry and Singh 1974 and Shetty et al., 2013). Different degrees of chlorosis and yellowing of veins and vein-lets, smaller leaves, fewer and smaller fruits, and stunting are the characteristic symptoms of YVMV. Fruit yield is also greatly reduced, as much as $96 \%$, if the crop is infected at early stage (Pun et al., 1999).

\section{Symptomatology}

The earliest symptom of BYVMV infected plants is vein clearing (Kulkarni, 1924) that starts on the small veins and extends to the larger ones (Uppal et al., 1940). Fernando and Udarvan (1942) reported that yellow vein banding may be followed by inter-veinal clearing and minute enations on the axial side of leaves. The fruits, arising from diseased plants, are malformed and bleached. Vein clearing is soon followed by veinalchlorosis (Capoor and Verma, 1950). Sometimes, the yellow network of veins is followed by thickening of veins and vein-lets (Nariani and Seth, 1958).In severe cases of infection, chlorosis is followed by complete yellowing of leaves (Raychaudhari and Nariani, 1977). The symptom of OYVM disease develops principally on leaves, as they are formed throughout the growth period of the plant. There is distinct vein clearing and venial chlorosis of the leaves.

\section{Pathogen}

The yellow vein mosaic disease of okra (YVMD) is caused by Bhendi yellow vein mosaic virus (BYVMV) and this virus is believed to be originated in India. It was first reported in 1924 from the erstwhile Bombay Presidency (Kulkarni, 1924). The virus is transmitted by whitefly (B. tabaci Genn.) in persistent manner by both nymph and adults. BYVMV is ssDNA spherical virus with 20 nm diameter (Mortelli, 1992).

According to Handa and Gupta (1993), the causal agent of yellow vein mosaic disease is a geminivirus of $18 \mathrm{~nm} \times 30 \mathrm{~nm}$ in size and it is in close relationship with Indian cassava mosaic geminivirus (ICMV) which was proved by ELISA by using ICMV polyclonal antiserum. Later, Pun et al., (1999) detected OYVMV in infected okra plants by direct antigen coating ELISA (DAC-ELISA) using polyclonal antibodies raised against African cassava mosaic virus and Indian cassava mosaic virus.

The virus belongs to the genus Begomovirus and family Geminiviridae (Fauquet and Stanley, 2005). This disease is caused by a complex consisting of the monopartite begomovirus bhendi yellow vein mosaic virus and a small satellite DNA beta component. YVMV can systemically infect bhendi upon agro-inoculation but produces only mild leaf curling symptoms. However, DNA beta induces typical symptoms of bhendi (okra) yellow vein mosaic when co-agro-inoculated with the begomovirus to bhendi. 


\section{Materials and Methods}

\section{Cytopathological studies}

\section{Materials}

For the studies of cytopathological - Petri plates, distilled water, section (healthy and diseased), staining chemical, ethanol, glass watch, slide, brush, razor blade, styrofoam, microscope with microphotography and installed software for measurement are used.

\section{Collection and preservation of diseased and healthy samples}

Cytopathological studied work out in Plant Pathology lab. From the experimental field, samples were collected infected and healthy (healthy from net protected) (leaf midrib) which was same cultivar and these samples are preserved in F.A.A. solution $(10.0 \mathrm{ml}$ formalin $+5.0 \mathrm{ml}$ glacial acetic acid +50.0 $\mathrm{ml}$ ethanol $+35.0 \mathrm{ml}$ distilled water) as per Mohamed et al. (2012).

\section{Preparation of staining solution}

Staining solutions are prepared by $1.0 \mathrm{~g}$ Azure A dissolved in $25.0 \mathrm{ml}$ of ethanol and preserved as stock solution and similarly 0.2 $\mathrm{M}$ solution of $\mathrm{Na}_{2} \mathrm{HPO}_{4}$ in distilled water were prepared $\left(2.9 \mathrm{~g} \mathrm{Na}_{2} \mathrm{HPO}_{4}+100.0 \mathrm{ml}\right.$ distilled water) and kept as stock solution. The final solution was prepared by mixing of Azure A stain stock solution with $\mathrm{Na}_{2} \mathrm{HPO}_{4}$ in the $1: 9$ ratio $(1.0 \mathrm{ml}$ Azure A stock solution + $9.0 \mathrm{ml} \mathrm{Na} \mathrm{HPO}_{4}$ solution). For each batch of tissues, fresh staining solution was made from the stock solutions (Christie and Edwardson, 1986). In case of excess staining, the sections were floated in 2-methoxyethylacetate to drain off excess stain and, thereafter, the sections were mounted directly on glycerin and covered with cover slip and observed for cytopathological changes under the microscope NIKON eclipse 50i attached with microphotography system at room temperature.

\section{Methods}

Free hand sections, from these samples (healthy and diseased), were cut using ordinary razor blade with help of styrofoam packing material from previously stored tissues (infected and healthy). The cut thin and uniform sections, after selections, were washed in distilled water by shaking with the help of fine hair brush. Sections were dehydrated in 2-methoxy-ethanol solution in watch glass for $30 \mathrm{~min}$ to clear away all pigments. Stored sections, cut in 2-methoxyethanol solution, were washed in same giving two changes. After that, these sections were transferred to staining solution (Azure A stain), kept in watch glass, for staining for 510 minutes. These sections were observed for cytopathological changes under microscope NIKON eclipse 50i attached with microphotography system.

\section{Results and Discussion}

For the cytopathological studies, free hand sections were cut from healthy and diseased mid-vein using simple razor blade in the 2methoxy ethanol. These sections were stained in Azure A stain to observed the cytopathological changes happened, if any. Azure A stain imparts red magenta color to the inclusions rich in ribo-nucleoprotein and blue to blue violet color to inclusion rich in deoxy-ribo-nucleoprotein (Edwardson and Christie, 1983).

\section{Healthy mid-vein tissues}

The microphotographs of phloem region of the healthy mid-vein sections illustrate that there was no any reaction of Azure A stain. Considerable numbers of sections, from 
healthy mid-vein, were examined and none of these retained the stain (blue to blue violet color). Nuclei of the healthy mid-vein cells were also remained free from the stain (Figs. 1 and 2).

\section{Diseased mid-vein tissues}

The microphotographs of phloem region of the healthy mid-vein sections illustrate that there was reaction of Azure A stain. Considerable numbers of sections, from diseased mid-vein, were examined and all of these retained the stain (blue to blue violet color). Nuclei of the healthy mid-vein cells were also retained the blue color of stain. The retaining of blue color by the phloem cells of diseased mid-vein indicates the presence to foreign deoxy-ribo-nucleoprotein in comparison of phloem of healthy mid-vein sections. At higher magnification, inclusion in the nucleus of diseased phloem cells were clearly visible (Fig. 3).

\section{Cytopathology changes}

Among the most important cytopathological effect of the viral infection are changes in nuclei. In the present study, the mid-vein sections of diseased and healthy were stained with Azure A stain. The phloem region of diseased mid-vein retained blue color indicating the presence of foreign deoxy-ribonucleoprotein (Christie and Edwardson, 1986) (Figs. 3-6).

Fig.1 Transverse section of healthy mid-vein showing no retention of blue color by phloem after the staining with azure A stain (100x)

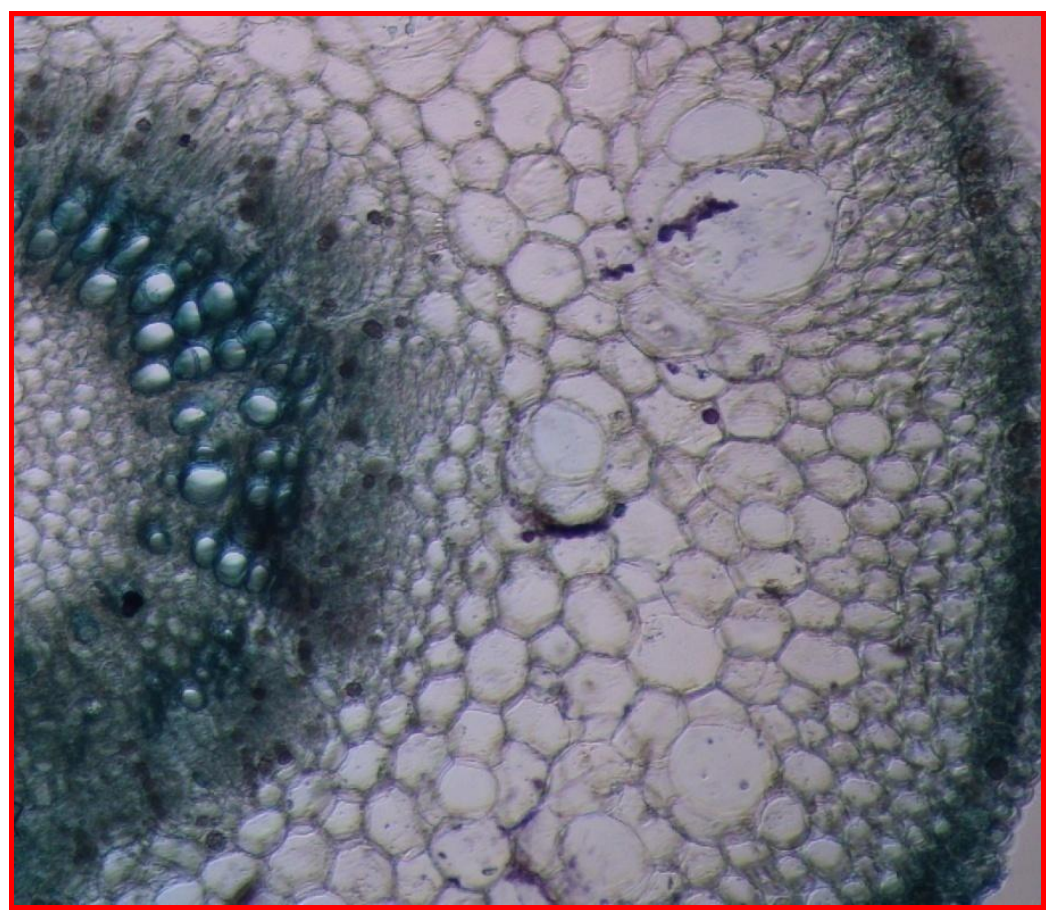


Fig.2 Transverse section of healthy mid-vein showing no retention of blue color by phloem after the staining with azure A stain (400x)

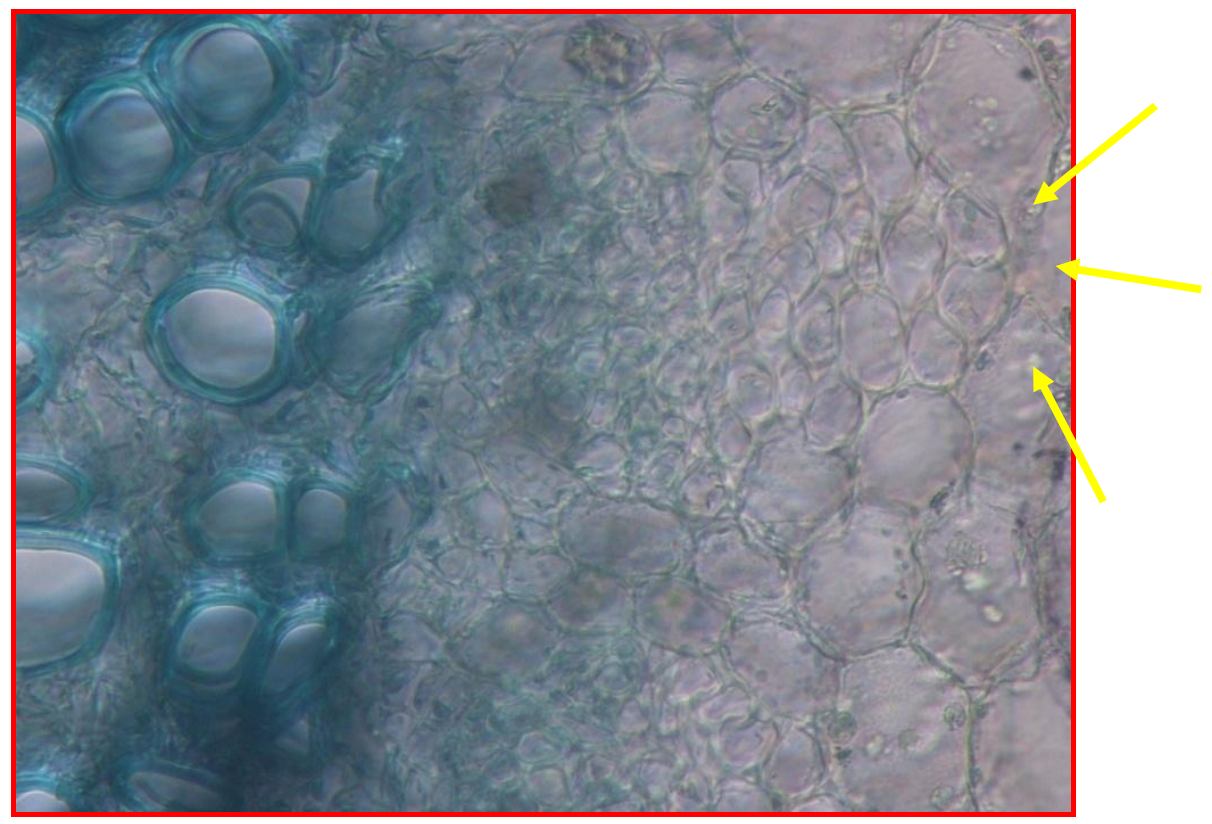

Fig.3 Transverse section of diseased mid-vein of okra showing retention of blue color after staining with azure A stain under green filter at 400x

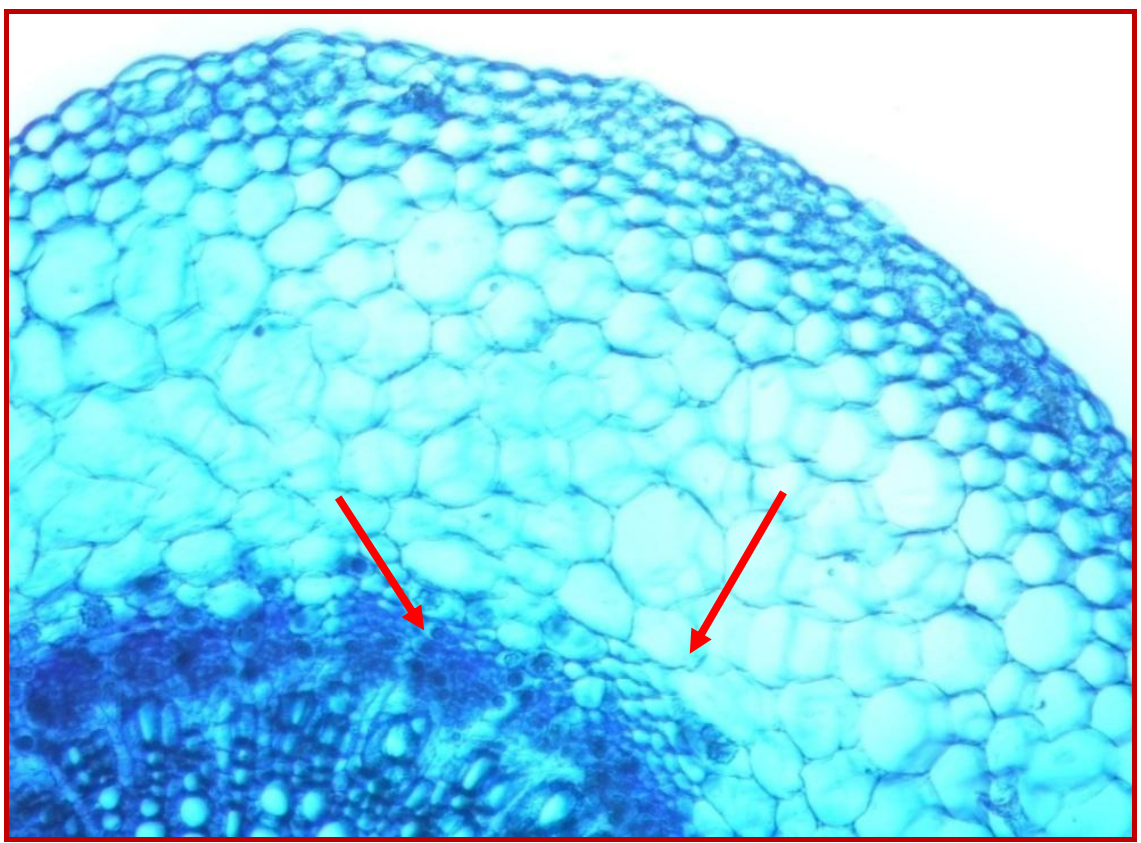


Fig.4 Transverse section of diseased mid-vein of okra showing retention of blue color after staining with azure A stain at 400x

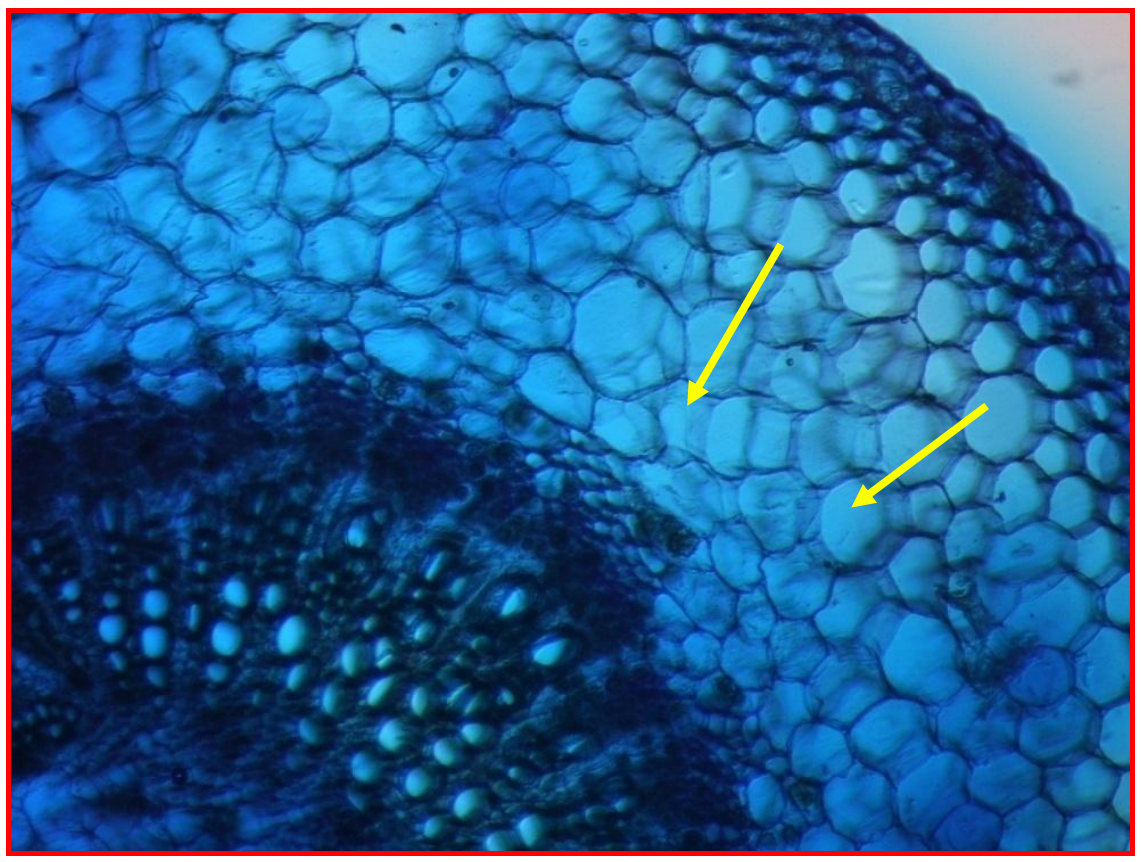

Fig.5 Transverse section of diseased mid-vein of okra showing enlarge nucleus with hypertrophied nucleolus at 1000x

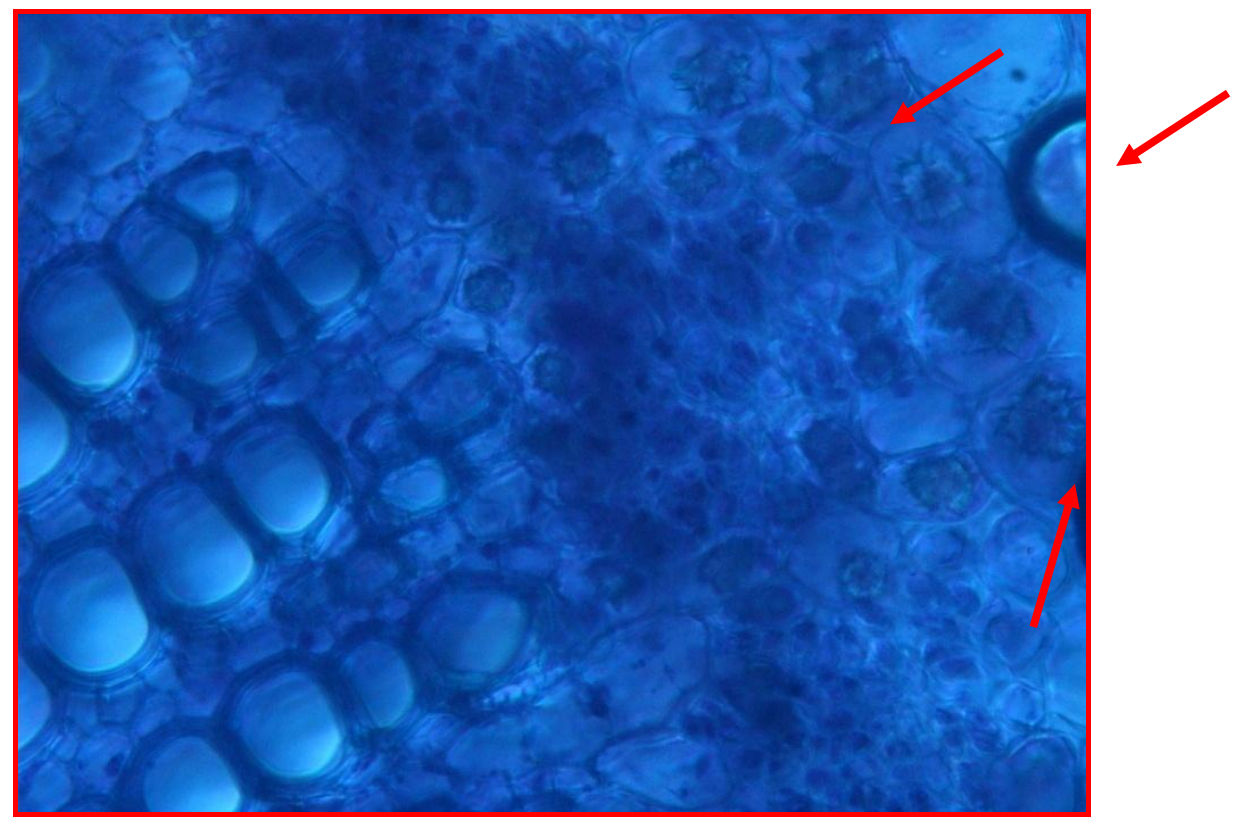


Fig.6 Transverse section of diseased mid-vein of okra showing enlarge nucleus with hypertrophied nucleolus at 1000x under sepia filter

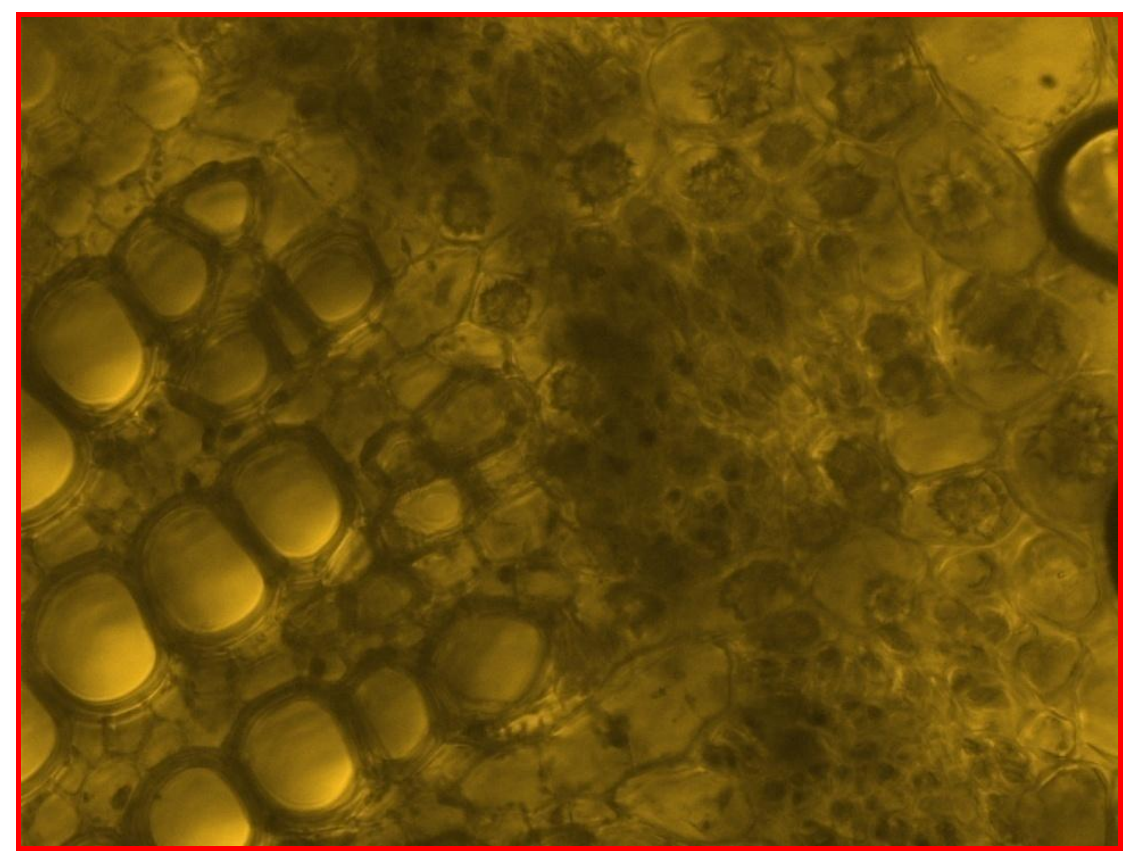

Examination of stained mid-vein sections, from diseased plants, revealed the presence of virus induced structure in the nucleus of phloem cells. Because this induced modification, nucleolus of nucleus has occupied $34^{\text {th }}$ part of the nucleus. Such type of structures have also been observed by Rushing et al., (1987) in tobacco plants infected with tomato golden mosaic virus (TGMV). Similarly, Kim et al., (1978) reported that bean golden mosaic virus (BGMV), in Phaseolus vulgaris plants, induced striking changes in the nuclear structure including hypertrophy of nucleolus so that it occupied up to $3 / 4^{\text {th }}$ of the nuclear volume and appearance of electron- dense condensed fibrillar rings in various numbers and sizes. They also reported that only phloem cells showed nucleopathic effects and virus particles were present only in the nucleus of these cells. Edwardson and Christie (1983) observed nuclear inclusion in Nicotiana clevelandii infected with potato virus. Gracia and Shephered (1985) reported that nuclei of Nicotiana plants, infected with cauliflower mosaic virus (CaMV), became greatly enlarged and filled with virions. Chanarayappa et al., (1992) recorded hypertrophy of nucleolus in tomato plants infected with tobacco leaf curl virus (TLCV).

\section{References}

Akanbi, W. B., Togun, A.O., Adeliran, J. A. and Ilupeju, E. A. O. 2010. Growth dry matter and fruit yields components of okra under organic and inorganic sources of nutrients. American-Eurasian Journal of Sustainable Agriculture, 4: 1-13.

Baloch, A. F., Qayyum, S. M. and Baloch, M. A. 1990. Growth and yield performance of okra (Abelmoschus esculentus L) cultivars. Gomal University Journal of Research, 10: 191.

Capoor, S. P. and Verma, P. M. 1950. Yellow vein mosaic of Hibiscus 
esculentus L. Indian Journal of Agriculture Science, 20: 217-230.

Channarayappa, C., Muniyappa, V., Schwegler, B. D. and Shivashankar, G. 1992. Ultrastructural changes in tomato infected with tomato leaf curl virus, a whitefly transmitted geminivirus. Canadian Journal of Botany, 70 (9): 1747-1753.

Christie, R. G. and Edwardson, J. R. 1986. Light microscopy techniques for the detection of plant virus inclusions. Florida Agricultural Experimentation Station pp 09.

Deshmukh, N. D., Jadha,v B. P., Halakude, I. S., and Rajput, J. C. 2011. Identification of new resistant sources for yellow vein mosaic virus disease of Okra (Abelmoschus esculentus L.). Vegetable Science, 38(1): 79-81.

Edwardson, J. R. and Christie, R. G. 1983. Cytoplasmic cylindrical and nucleolar inclusions induced by potato virus-A. Phytopathology 73: 290-293.

Fauquet, C. M. and Stanley, J. 2005. Revising the way we conceive and name viruses below the species level: a review of geminivirus taxonomy calls for new standardized isolate descriptors. Archive Virology, 150: 2151-2179.

Fernando, M. and Udurawana, S. B. 1942. The nature of the mosaic disease of Banbakka (Hibiscus esculentus L.). Tropical Agriculturist, 18(1): 16-24.

Gracia, O. and Shepherd, R. J. 1985. Cauliflower mosaic virus in the nucleus of Nicotiana. Virology 146: 141-145.

Hamer, C. and Thompson, T. 1957. Vegetable crops. McGraw Hill Co., Inc. N. X. Toronto, London.

Handa, A., and Gupta, M. D. 1993. Management of bhendi yellow vein mosaic virus. Indian Phytopathology, 46 (2): 123-130.

Kim, K. S., Shock, T. L. and Robert, M. 1978. Infection of Phaseolus vulgaris by bean golden mosaic virus: ultrastructural aspects. Virology, 89, (1): 1-346

Kulakarni G S (1924). Mosaic and other related diseases of crops in the Bombay presidency. Poona Agriculture College Magazine, 16: 6-12.

Kumar, S., Dagnoko, S., Haougui, A., Ratnadass, A., Pasternak, D. and Kouame, C. 2010. Okra (Abelmoschus spp.) in West and Central Africa: potential and progress on its improvement. African Journal of Agriculture Research, 5: 3590-3598.

Martelli. 1992. Classification and nomenclature of plant viruses: state of art. Plant Disease, 76 (5): 436-442.

Mohamed, E. F., Farag, A. G., Osman, T. A. M. and Eman, A. A. 2012. Histopathological changes in leaves cells of squash plants infected with Squash leaf curl begomovirus (SqLCV). Report and Opinion, 4(5): 65-75.

Nariani, T. K. and Seth, M. L. 1958. Reaction of Abelmoschus and Hibiscus species to yellow vein mosaic virus. Indian Phytopathology, 11:137-140.

Pun, K. B., Doraiswamy, S. and Jeyarajan, R. 1999. Immunological detection of okra yellow vein mosaic virus. Indian Journal of Virology, 16(2): 93-96.

Raychoudhuri, S. P. and Nariani, T. K. 1977. Viruses and mycoplasm diseases of plants in India. Oxford and IBH Publication Company, New Delhi, 160167.

Rushing, A. E., Sunter, G., Gardiner, W. E., Dute, R. R. and Bisaro, D. M. 1987. Ultrastructural aspects of tomato golden mosaic virus infection in tobacco. Phytopathology, 77: 1231-1236.

Sastry, K. S. M. and Singh, S. J. 1974. Effect of yellow vein mosaic virus infection on growth and yield of okra crop. Indian Phytopathology, 27(2): 294-297.

Setty, A. A., Singh, J. P. and Singh, D. 2013. Resistance to yellow vein mosaic virus 
in okra: a review. Biological Agriculture and Horticulture: An International Journal for Sustainable Production System, 29(3): 159-164.

Uppal, B. N., Varma, P. M. and Capoor, S P. 1940. Yellow vein mosaic of bhendi. Current Science, 9: 227-228.
Usha, R. 2008. Bhendi yellow vein mosaic virus. In: Rao $G$ P, Kumar $P$ L, Holguin-Pena R J (editors) Characterization, diagnosis and management of plant viruses, Studium Press, Houston, 3: 387-392.

\section{How to cite this article:}

Markam, V.K., A.K. Singh, Narayan Lal and Shailendra Kumar. 2017. Cytopathological Changes Induced by Yellow Vein Mosaic Virus in Mid-Vein of Infected Okra Plant. Int.J.Curr.Microbiol.App.Sci. 6(6): 2477-2485. doi: https://doi.org/10.20546/ijcmas.2017.606.294 